\title{
OBSERVATIONS OF GLACIER SEISMICITY ON UNTERAARGLETSCHER
}

\author{
By N. Deichmann, J. Ansorge, \\ (Institut für Geophysik, Eidg. Technische Hochschule-Hönggerberg, 8093 Zürich, \\ Switzerland)
}

and $\mathrm{H}$. RöthlisBerger

(Versuchsanstalt für Wasserbau, Hydrologie und Glaziologie, Eidg. Technisch HochschuleZentrum, Gloriastrasse 37/39, 8092 Zürich, Switzerland)

ABstract. Almost continuous recordings of glacier seismicity were obtained on Unteraargletscher (Berner Oberland, Switzerland) over a period of two weeks at the end of May 1977. The seismograph array consisted of micro-earthquake recorders, some recording directly onto smoked paper (three Sprengnether model MEQ-8oo) and others recording onto magnetic tape (one MARS-72 apparatus and two seismic-event recorders). The frequency range covered by the instruments lies between $\mathrm{I}$ and $85 \mathrm{~Hz}$. The array spanned a relatively crevassefree area of about $500 \mathrm{~m}$ by $700 \mathrm{~m}$.

At the beginning of the period of observation only a few events were recorded per hour. Probably as a consequence of increased run-off of melt and rain, which acted as a lubricant or as an agent of hydraulic fracturing within or beneath the glacier, the activity rose in two days to a maximum of 120 events in one hour, and then with minor fluctuations it gradually decreased again to its initial level. The variations in activity showed signs of correlating with the velocity measurements, which however were only started after the main maximum, but did not seem to be influenced by the uplift of the glacier surface or by the diurnal meteorological fluctuations.

Most of the recorded signals could be classified according to their frequency content into three groups: 40, 20, and $5 \mathrm{~Hz}$. The $40 \mathrm{~Hz}$ events, whose duration was less than I s, are located near the glacier surface and probably correspond to those attributed by Neave and Savage (1970) to the formation of crevasses. The majority of the events were of the $20 \mathrm{~Hz}$ type, each of about I s duration. Due to inadequacies in the seismometer array, only three of them could be located with sufficient accuracy: they originated in different areas of the glacier at a depth of about $150 \mathrm{~m}$, which is strong evidence that icequakes are not, as previously thought, limited to the upper $40 \mathrm{~m}$. The signals of the $5 \mathrm{~Hz}$ type, lasting several seconds, are thought to be $20 \mathrm{~Hz}$ events whose higher frequencies have been attenuated by a longer travel path. The lower-frequency signals from the glacier bed, reported by Bindschadler (unpublished) and by Weaver and Malone (1979), were not observed. This could indicate that a variety of mechanisms are operative at different times of year. In particular, the subglacial conduits were only poorly developed in Unteraargletscher at the time of these recordings.

\section{REFERENGES}

Bindschadler, R. A. Unpublished. Monitoring the seismic activity of a surge-type glacier. [Report on field glaciology. Graduate Program in Geophysics, University of Washington, Seattle, Washington 98195, U.S.A.,

1975.]
Neave, K. G., and Savage, J. C. 1970. Icequakes on the Athabasca Glacier. Journal of Geophysical Research, Vol. 75, No. 8 , p. $135^{1-62}$.

Weaver, C. S., and Malone, S. D. 1979. Seismic evidence for discrete glacier motion at the rock-ice interface. Journal of Glaciology, Vol. 23, No. 89, p. $171-84$. 